\title{
Jurassic dinoflagellate cysts from Hochstetter Forland, North-East Greenland
}

\author{
Stefan Piasecki and Lars Stemmerik
}

\begin{abstract}
Three sections in Hochstetter Forland, North-East Greenland, referred to the Jurassic Payer Dal and Bernbjerg Formations, have been analysed for dinoflagellate cysts. The dinoflagellate cysts, new finds of ammonites and previously recorded marine faunas form the basis for improved dating of the succession. The basal strata of the Payer Dal Formation at Kulhus is here dated as Late Callovian, Peltoceras athleta Chronozone, based on the presence of relatively abundant Limbicysta bjaerkei, Mendicodinium groenlandicum, Rhychoniopsis cladophora and Tubotuberella dangeardii in an otherwise poor Upper Callovian dinoflagellate assemblage. Ammonites have not been recorded from these strata. The upper Payer Dal Formation at Agnetesøelven is dated as Late Oxfordian, Amoeboceras glosense-Amoeboceras serratum Chronozones, based on the presence of Sciniodinium crystallinum, together with Cribroperidinium granuligera and Stephanelytron sp. The age is in accordance with ammonites present in the uppermost part of the formation at Søndre Muslingebjerg. New ammonites in the Bernbjerg Formation at Agnetesøelven together with dinoflagellate cysts indicate an earliest Kimmeridgian age, Rasenia cymodoce and Aulacostephanoides mutabilis Chronozones.

The Upper Callovian dinoflagellate cysts from Hochstetter Forland belong to a local brackish to marginal marine assemblage, which only allows a fairly broad correlation to coeval assemblages in central East Greenland. In contrast, the Oxfordian and Kimmeridgian assemblages are fully marine and can be correlated from Milne Land in central East Greenland via Hochstetter Forland to Peary Land in eastern North Greenland.
\end{abstract}

Keywords: ammonites, Boreal, dinoflagellate cysts, Hochstetter Forland, Jurassic, North-East Greenland

Geological Survey of Denmark and Greenland, Øster Voldgade 10, DK-1350 Copenhagen K, Denmark. E-mail: sp@geus.dk

The northernmost onshore Jurassic outcrops in East Greenland occur in Hochstetter Forland and, some 60$80 \mathrm{~km}$ farther north, on Store Koldeway (Fig. 1); the stratigraphy of the latter area is described in an accompanying paper (Piasecki et al. 2004a, this volume). The Hochstetter Forland peninsula is dominated by flat lowlands dissected by small streams; outcrops of pre-Quaternary sediments are restricted to stream cuts and low coastal cliffs scattered throughout the region (Fig. 1). However, at Søndre Muslingebjerg to the south, Caledonian basement and Middle-Upper Jurassic sandstones and coals are faulted and reach up to approximately $400 \mathrm{~m}$ above sea level. Caledonian basement and Jurassic sediments also crop out in northern Hochstetter Forland, east of Agnetes $\varnothing$, and the meanders of Agnetesøelven (the river from Agnetes $\varnothing$ to the coast) erode into marine Jurassic sediments deposited on basement rocks (Fig. 1).

The Jurassic stratigraphy of the Hochstetter Forland area is based on records of marine faunas including ammonites from several isolated exposures (Ravn 1911; Surlyk 1978). The lowermost deposits consist of the non-marine to marginal marine Muslingebjerg Formation, which is undated owing to the absence of marine fossils. The overlying sands of the Payer Dal Formation contain Upper Oxfordian ammonites in the upper 


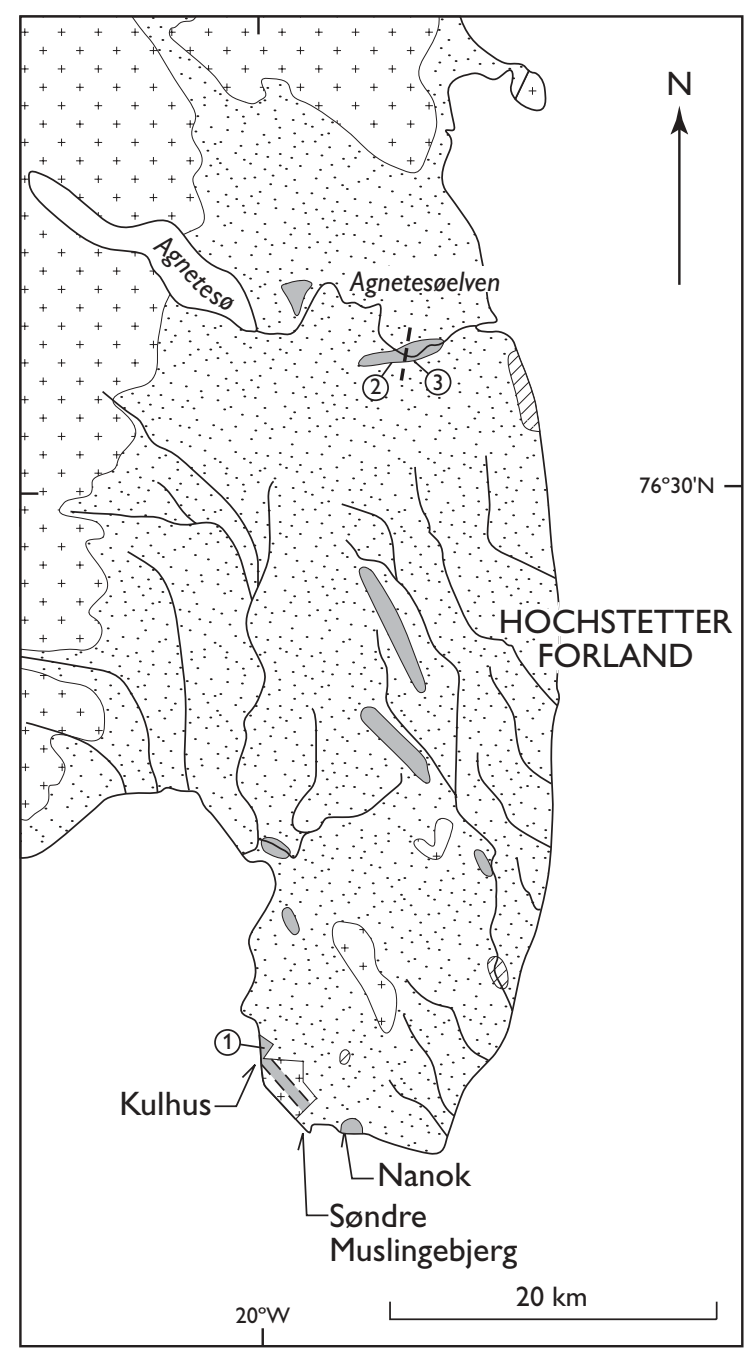

Fig. 1. Simplified sketch map of Hochstetter Forland illustrating the Jurassic outcrops and the sampled localities. The map is modified from Surlyk (1978, fig. 1). part, and are followed by mudstones of the Bernbjerg Formation that yield Upper Oxfordian - Lower Kimmeridgian ammonites (Surlyk 1978). The outcrops at Kulhus and Agnetesøelven expose the main part of the Jurassic succession in Hochstetter Forland. These localities were visited during fieldwork in 1987 in order to collect material for palynological analysis with the aim of refining the stratigraphy. The present paper describes for the first time the dinoflagellate cyst floras from these northern outcrops close to the transition to the Boreal dinoflagellate cyst province, for example in Peary Land (Håkansson et al. 1981) and on Svalbard (Århus 1988).

\section{Material}

At Kulhus (Fig. 1; Locality 1), on the south coast of Hochstetter Forland west of Søndre Muslingebjerg, sand and coal seams were sampled during a ground stop on helicopter reconnaissance in 1987. Only one sample (GGU 351570) contains dinoflagellate cysts. Two closely situated localities at Agnetesøelven were spotted from the air and visited during a short ground stop. The westernmost sandstone outcrop (Locality 2) was measured and two fine-grained samples with at least some potential for palynology were collected from two horizons (Fig. 2). Eastwards and down-river, the sandstone-dominated succession was seen to be faulted against a succession of laminated mudstones (Locality 3 ), and this was closely sampled for palynology (Fig. 3). Only a few, well-preserved dinoflagellate cysts were recovered from the sand succession at Locality 2. By 
Fig. 2. Sedimentological log of the upper Payer Dal Formation at Agnetesøelven (Locality 2) showing the positions of analysed samples.

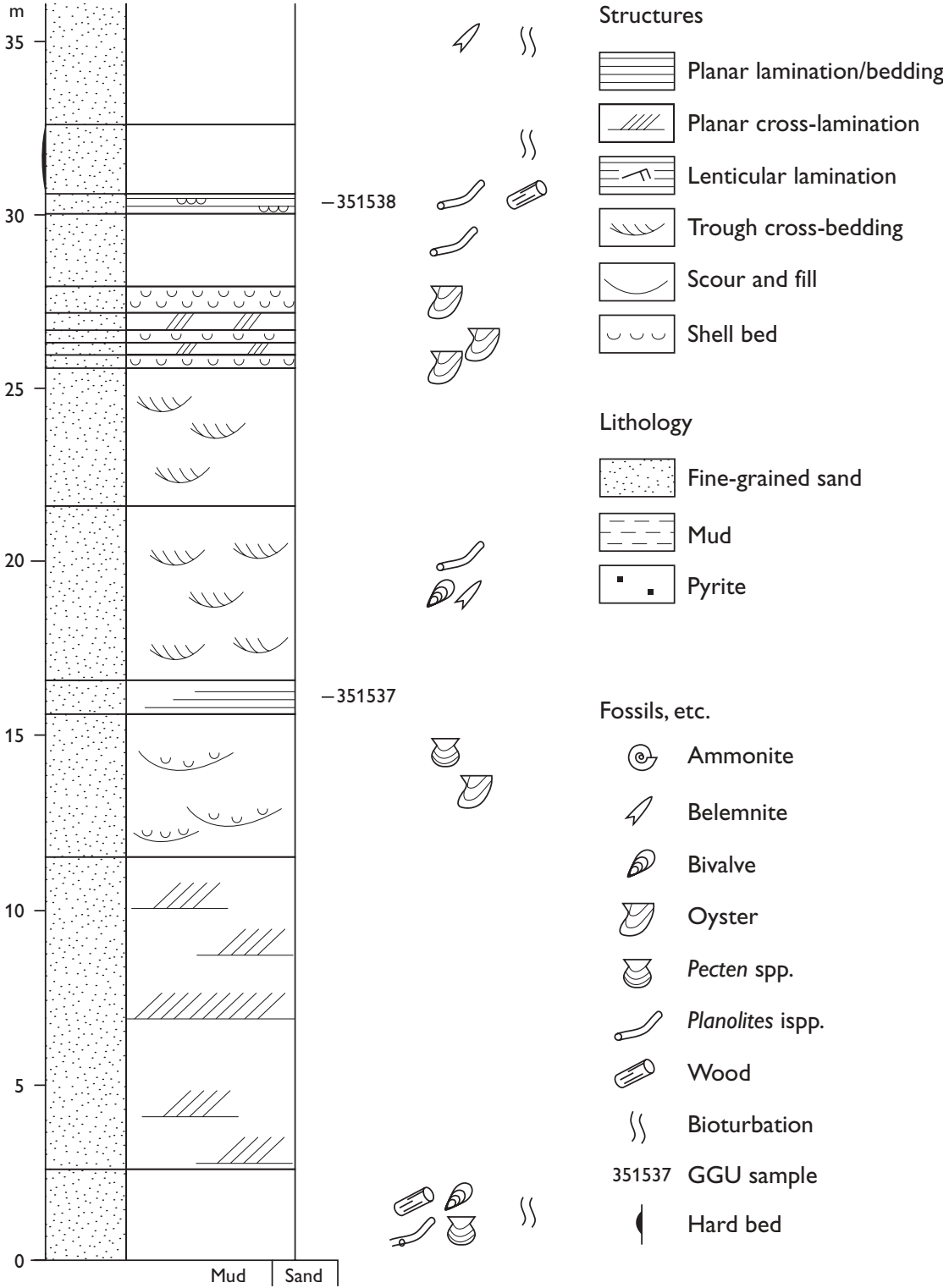

contrast dinoflagellate cysts are abundant but poorly preserved in the mudstones at Locality 3. Ammonites are abundant in the lower, pyritic, part of the mudstone succession and in loose concretionary beds at the base of the cliff. These ammonites provide independent stratigraphical control of the dinoflagellate cyst assemblages.

All of the samples from the three localities on Hochstetter Forland were prepared by traditional palynological methods and analysed for their content of dinoflagellate cysts.

\section{Geology}

The Jurassic succession on Hochstetter Forland is divided into the Muslingebjerg, Payer Dal and Bernbjerg Formations of the Vardekløft Group. The marine sandstones of the Payer Dal Formation were previously included in the Pelion Member of the Vardekløft Formation (sensu Surlyk 1978); the Pelion Member is now raised to formation status (Surlyk 2003, fig. 5).

\section{Kulhus (Locality 1)}

The low coastal cliff at Kulhus, south-west Hochstetter Forland (Fig. 1, Locality 1), comprises 3-4 main coal 


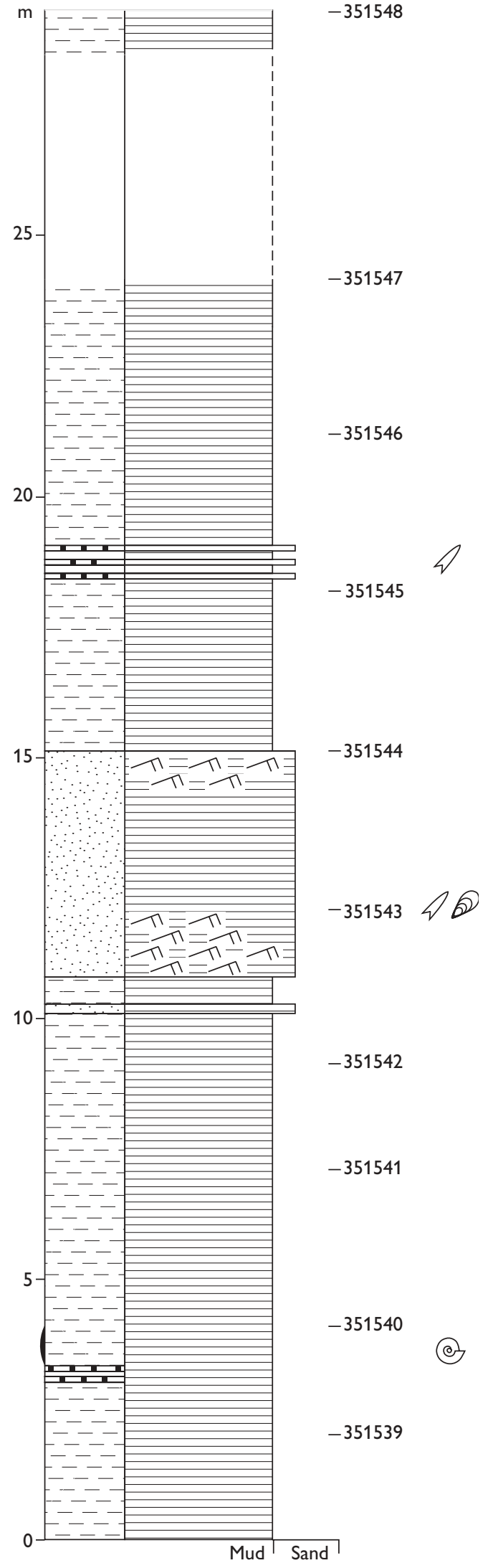

Fig. 3. Sedimentological log of the Bernbjerg Formation at Agnetesøelven (Locality 3) showing the positions of analysed samples. For legend, see Fig. 2.

seams interbedded with black carbonaceous shales and light-coloured sandstones of the Muslingebjerg Formation (Clemmensen \& Surlyk 1976). No marine fossils have been recorded from the formation but the high sulphur content of the coals and shales suggests a marine depositional environment (Petersen et al. 1998). The Jurassic succession at Kulhus extends up the western flank of Søndre Muslingebjerg where the stratigraphically highest strata contain Upper Oxfordian ammonites referable to the Amoeboceras glosense and/ or A. serratum Zones (Ravn 1911; Sykes \& Surlyk 1976).

Coals and shales of the Muslingebjerg Formation have been prepared palynologically without finding any microscopic marine fossils. At Kulhus, the first dinoflagellate cysts appear in the basal mudstone bed of the overlying Payer Dal Formation, immediately above the highest coal seam, at the same level as the earliest marine faunas. Restricted assemblages of sporomorphs from the underlying coals indicate an overall Jurassic age.

\section{Agnetesøelven (Localities 2 and 3)}

Fine-grained sandstone, with abundant marine fossils, is exposed at Locality 2 and referred to the Payer Dal Formation (Figs 1, 2). Shell beds of Pecten spp., oysters, other bivalves and serpulids occur throughout the succession and are commonly concentrated in scour fills. Belemnites are present, but no ammonites were recovered during the short visit. Woody material and small logs are also common. The sandstone is intensely bioturbated and many sedimentary structures are obliterated although cross-bedding or lamination is recognisable in most beds. Planolites ispp. is common at certain horizons.

The shale succession exposed at Locality 3 is referred to the Bernbjerg Formation. It consists of laminated, dark mudstones alternating with lenticular-bedded, fine-grained, grey sandstones (Fig. 3). Ammonites and bivalves are abundant in a concretionary bed low in the section and belemnites and bivalves occur scattered higher in the succession. The concretionary beds are washed out from the lowermost succession and lie at the foot of the cliff. They contain accretions of ammonites in several stacked laminae together with abundant Buchia sp. Abundant male and female individuals occur together in the ammonite assemblages (J.H. 


\begin{tabular}{|c|c|c|c|}
\hline LITHOSTRATIGRAPHY & BIOSTRATIGRAPHY & \multicolumn{2}{|c|}{ CHRONOSTRATIGRAPHY } \\
\hline FORMATION & AMMONITE ZONE & $\begin{array}{c}\text { AGE BASED ON } \\
\text { DINOFLAGELLATE CYSTS }\end{array}$ & CHRONOZONES \\
\hline Bernbjerg & $\begin{array}{l}\text { A. mutabilis } \\
\text { R. cymodoce }\end{array}$ & $\begin{array}{c}\text { Early } \\
\text { Kimmeridgian }\end{array}$ & $\begin{array}{l}\text { A. mutabilis } \\
\text { R. cymodoce }\end{array}$ \\
\hline Payer Dal & A. glosense -A. serratum & $\begin{array}{l}\text { Late Oxfordian } \\
\text { Late Callovian }\end{array}$ & $\begin{array}{c}\text { A. glosense - A. serratum } \\
\text { P. athleta }\end{array}$ \\
\hline Muslingebjerg & No marine fossils & (Callovian?) & pre-P. athleta \\
\hline
\end{tabular}

Fig. 4. Summary of the Jurassic stratigraphy of Hochstetter Forland.

Callomon, personal communication 1999). The assemblage is equivalent to ammonite Fauna 15 from Milne Land in the lower Rasenia cymodoce Zone, Lower Kimmeridgian (Fig. 4; Birkelund \& Callomon 1985; J.H. Callomon, personal communication 1999). Lower Kimmeridgian ammonites have been reported previously from sandstones at the locality of Nanok in southern Hochstetter Forland (Frebold 1932). Ammonites of the lowermost Kimmeridgian Rasenia cymodoce and Aulacostephanoides mutabilis Zones, have been collected from mudstones of the Bernbjerg Formation in Hochstetter Forland (Frebold 1932; Surlyk 1978).

\section{Stratigraphy}

\section{Basal Payer Dal Formation (Locality 1)}

Dinoflagellate cysts. An unusual and relatively poor assemblage of dinoflagellate cysts was recorded immediately above the lithological transition from the barren Muslingeelv Formation to the fossiliferous Payer Dal Formation (Fig. 5). Limbicysta bjaerkei, Pilosidinium fensomei and Pareodinia halosa dominate the assemblage, in association with Gonyaulacysta jurassica, Nannoceratopsis sp., Occisucysta sp., Pareodinia sp., Solisphaeridium sp., Tubotuberella cf. dangeardii and Tubotuberella cf. egemenii. Single specimens of Atopodinium haromense, Mendicodinium groenlandicum and Rhynchodiniopsis cladophora were recorded.

Age. Stratigraphically diagnostic species are few in this assemblage. In East Greenland, Limbicysta bjaerkei has not been recorded stratigraphically higher than the basal Boreal Middle Jurassic in the Cranocephalites borealis Chronozone in Jameson Land (Milner \& Piasecki 1996). However, a stratigraphical range of Middle Callovian and possibly into lowermost Upper Callovian has been reported from both the Subboreal and Arctic regions (Smelror 1987, 1993). In Jameson Land, $M$. groenlandicum appears no lower than the Kosmoceras jason Chronozone (mid-Callovian) and distinct Rhynchodiniopsis cladophora and Tubotuberella dangeardii appear in the basal Upper Callovian in the Peltoceras athleta Chronozone (Milner \& Piasecki 1996). In conclusion, the sparse data indicate an age equivalent to the earliest Late Callovian, P. athleta Chronozone (Fig. 4). An Early Callovian age previously indicated for this unit (Petersen et al. 1998) was based on a sample that was subsequently found to be from another section and locality.

Depositional environment. The dinoflagellate cyst assemblage is dominated by three species (Fig. 5). Limbicysta bjaerkei is possibly an acritarch because no clear archaeopyle has been documented. The assemblage differs markedly from normal marine assemblages described from time equivalent strata in Milne Land (Piasecki 1996). Bailey \& Hogg (1995) reported abundant $L$. bjaerke $i$ in otherwise non-marine assemblages. This may indicate that the associated, frequent species, Pilosidinium fensomei and Pareodinia halosa, may have had similar environmental preferences. The abundance of $L$. bjaerkei - together with the restricted 
assemblage - is taken as evidence for estuarine, brackish depositional environments during the initial transgression of Hochstetter Forland.

\section{Upper Payer Dal Formation (Locality 2)}

Dinoflagellate cysts. Dinoflagellate cysts are relatively sparse in these sediments. However, the diversity is moderately good and the preservation is fine. Ambonosphaera calloviense is the only dinoflagellate species represented by more than one or two specimens in the assemblage (Fig. 5). Ambonosphaera calloviense, Sirmiodinium grossii and Sentusidinium sp. are the only species common to both samples.

Age. Despite the paucity of dinoflagellate cysts, the co-occurrence of Sciniodinium crystallinum, Cribroperidinium granuligera and Stephanelytron sp. indicates a Late Oxfordian age i.e. Amoeboceras glosense to Amoeboceras serratum Chronozones, by comparison to Hold with Hope and Milne Land further to the south (Piasecki 1996; Piasecki et al. 2004a, b, this volume; Figs 1, 4). None of the other dinoflagellate cysts are inconsistent with this age, which is also in accordance with the age indicated by ammonites from the uppermost Payer Dal Formation at Søndre Muslingebjerg (Ravn 1911; Sykes \& Surlyk 1976). However, the dinoflagellate cyst assemblage is too restricted to allow a more precise correlation.

Depositional environment. The low abundance combined with the moderate diversity of dinoflagellate cysts indicates near-shore marine deposition in a high-energy environment. The sandy sediments with a rich benthic fauna, partly in situ and partly reworked into shell beds, support this interpretation.

\section{Bernbjerg Formation (Locality 3)}

Dinoflagellate cysts. Dinoflagellate cysts are abundant and relatively diverse, but their preservation is poor. The composition of the assemblages varies significantly through the relatively short section (Fig. 5). Extremely abundant Sirmiodinium grossii characterises the lower part of the section and is gradually replaced by abundant Gonyaulacysta jurassica sensu lato in the upper part. Five other species appear in succession with distinct and characteristic maxima through the succession (Fig. 5). Abundant Nummus sp. occurs together with the maximum numbers of Escharisphaeridium pocockii in the lower part of the succession. This is followed closely by a maximum abundance of Cribroperidinium granuligera, then by a maximum of Perisseiasphaeridium pannosum (together with Gonyaulacysta jurassica sensu lato) and finally by maximum abundance of Occisucysta cf. monoheuriskos in the uppermost sample.

A comparable succession of dinoflagellate cyst assemblages has been recorded across the boundary of the Payer Dal and Bernbjerg Formations at Kløft II on Store Koldewey (Piasecki et al. 2004a, this volume). At this locality, a maximum of G. jurassica sensu lato is followed by abundant P. pannosum and Occisucysta cf. monobeuriskos, similar to that recorded from the upper part of the section at Agnetesøelven (Locality 3). Assemblages dominated by Nummus sp., E. pocockii and $C$. granuligera were not recorded at Store Koldewey, but these species are present. In contrast, the stratigraphically significant Paragonyaulacysta capillosa is abundant at Store Koldewey, whereas it is rare in the succession at Agnetesøelven.

Age. The succession cannot be older than Early Kimmeridgian based on the ammonite fauna in the basal strata, which is indicative of the lower Rasenia cymodoce Zone. This is in accordance with the dinoflagellate cyst assemblage of abundant Sirmiodinium grossii and frequent Gonyaulacysta jurassica, Adnatosphaeridium sp. and Paragonyaulacysta capillosa. To the south, on Milne Land, $P$. capillosa first appears in the $R$. cymodoce Chronozone and is followed by Perisseiasphaeridium pannosum in the succeeding Aulacostephanoides mutabilis Chronozone (Piasecki 1996). At Agnetesøelven, the appearance of $P$. pannosum higher in the succession accordingly indicates an age equivalent to the A. mutabilis Chronozone for this part of the succession (Fig. 4). Dinoflagellate cysts indicative of younger Jurassic strata were not recorded.

Lower Kimmeridgian ammonites have previously been recorded from the Bernbjerg Formation on Hochstetter Forland. An ammonite fauna referable to the $A$. mutabilis Zone has been recovered from the Nanok and Agnetesøelven regions (Frebold 1932; Surlyk 1978).

Depositional environment. The dinoflagellate cysts are strongly degraded. They are physically broken, and angular imprints of crystals and deep circular imprints of spherical pyrite framboids obscure the sculpture and structure of their walls. Together with the undisturbed lamination of the sediments, this indicates deposition 


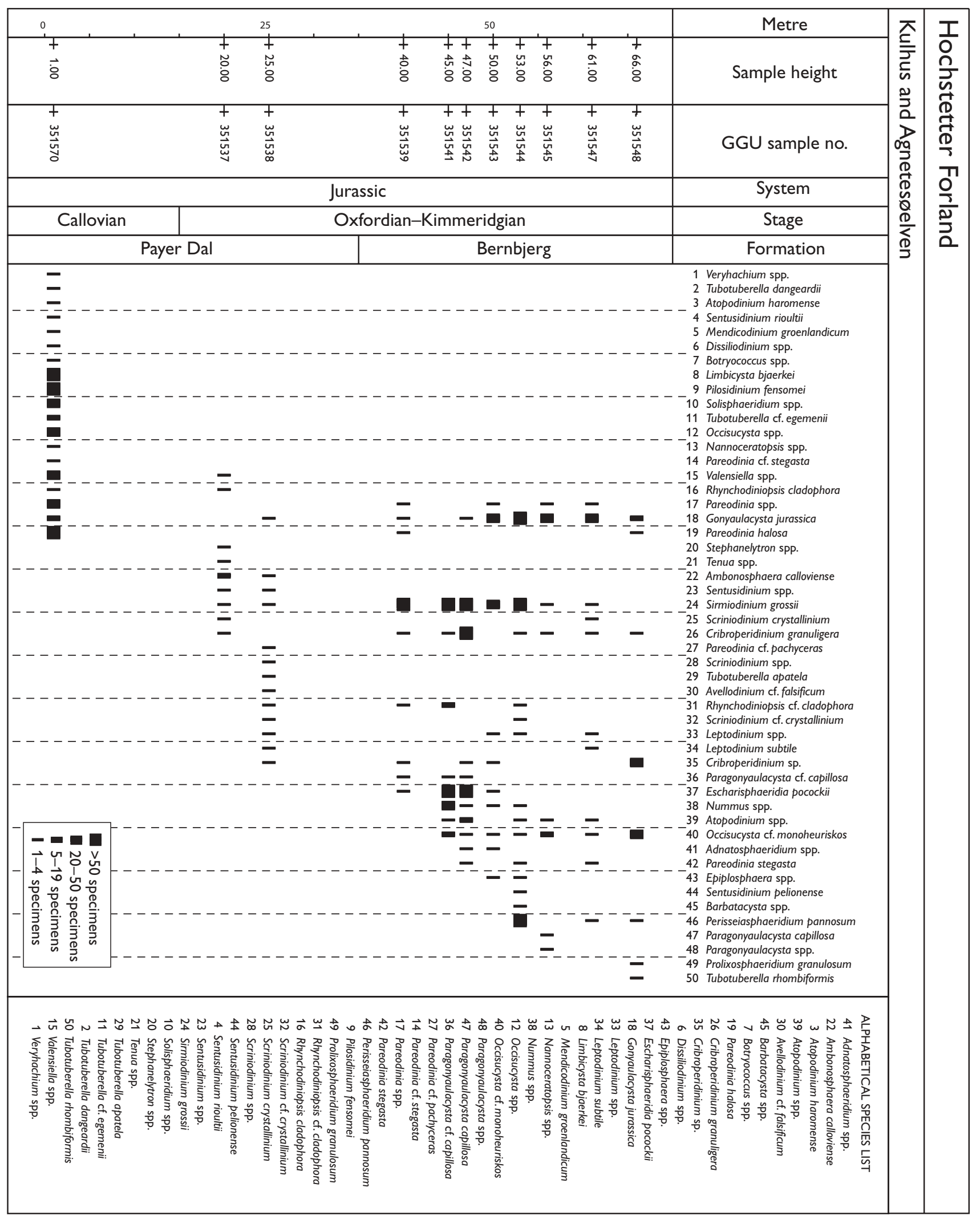

Fig. 5. Stratigraphical distribution chart of dinoflagellate cysts in samples from all three localities. The sample heights indicated are largely arbitrary, although the three localities are arranged in stratigraphic order. Sample at $1 \mathrm{~m}$ is from Locality 1 , samples at $20 \mathrm{~m}$ and $25 \mathrm{~m}$ are from Locality 2 (arbitrary spacing, see Fig. 2 for correct locations) and samples at 40-66 m are from Locality 3 (spacings approximately to scale, see Fig. 3 for precise locations). The recorded species are arranged by their first stratigraphical appearance. 
below wave base in a low-oxygenated environment. Lenticular laminae with small-scale ripples, however, show that the bottom water was not completely stagnant and that the sea floor was periodically swept by weak bottom currents.

\section{Correlation}

Studies of the Jurassic ammonite and dinoflagellate cyst stratigraphy in East Greenland, combined with sedimentological studies and sequence stratigraphical interpretations, contribute towards an integrated model in which units can be identified by their content of dinoflagellate cysts. The present study of the dinoflagellate cyst assemblages on Hochstetter Forland contributes basic data to this complex study.

The assemblage dominated by Limbicysta bjaerkei in the basal Payer Dal Formation at Kulhus has not been recorded anywhere else in East Greenland. This assemblage comprises the first marine fossils to have been deposited above the coal-bearing floodplain environment of the Muslingebjerg Formation. The dinoflagellate cyst assemblage records deposition in a marginal marine to brackish environment. The overlying sandstones are interpreted as tidal facies followed by shoreface facies (Petersen et al. 1998), reflecting a rise in relative sea level. This assemblage thus characterises marginal marine environments at the feather-edge of the Jurassic depositional basin during a major drowning event (Alsgaard et al. 2003).

The poor dinoflagellate cyst assemblage in the upper Payer Dal Formation is not representative of this stratigraphic interval, compared to the assemblages recorded from other localities in East Greenland. However, it is associated with a stratigraphic unit equivalent to the $A$. glosense and A. serratum Chronozones that previously has been identified throughout East Greenland, i.e. in Milne Land, Jameson Land and Hold with Hope (Engkilde 1994; Piasecki 1996; Vosgerau et al. 2004, this volume).

The dinoflagellate cyst assemblage from the Bernbjerg Formation at Agnetesøelven is known from Milne Land in the south to Store Koldewey in the north, and a similar assemblage occurs in the Ladegårdsåen Formation in Peary Land, North Greenland (Fig. 1; Piasecki 1966; Piasecki et al. 2004a, this volume). The dinoflagellate cyst assemblage correlates with the $R$. cymodoce and A. mutabilis Chronozones. It is associated with a major Kimmeridgian flooding event which allowed more permanent shelf anoxia to spread to shallow shelf areas of East Greenland (Milne Land, Wollaston Forland, Hold with Hope, Store Koldewey) and North Greenland (Peary Land). Maximum flooding occurred in the A. mutabilis to A. eudoxus Chrons.

\section{Conclusions}

New ammonite data confirm and refine earlier age determinations of the Jurassic succession on Hochstetter Forland. The age of the upper Payer Dal Formation in Hochstetter Forland is confirmed as Late Oxfordian, and the age of the Bernbjerg Formation is confirmed as earliest Kimmeridgian.

The dinoflagellate cyst stratigraphy from the three localities is fragmentary. The assemblage from the lower Payer Dal Formation at Kulhus has not been reported from any other section in East Greenland; it is important because it represents marginal marine conditions associated with a major flooding event of earliest Late Callovian age, P. athleta Chronozone (Fig. 4). This limits the age of the Muslingeelv Formation upwards. The assemblage in the upper Payer Dal Formation is restricted, but supports the previously recorded Late Oxfordian age, corresponding to the A. glosense and/ or A. serratum Chronozones. The third assemblage is well known from East Greenland and dates the Bernbjerg Formation at Agnetesøelven to the earliest Kimmeridgian, $R$. cymodoce and A. mutabilis Chronozones (Fig. 4). This assemblage is associated with a major transgressive event characterised by extensive shelf anoxia in East Greenland.

\section{Acknowledgements}

The work was initiated as part of the project 'Resources of the sedimentary basins of North and East Greenland' supported by the Danish Research Councils and completed by support from the Carlsberg Foundation Ans. 980089/0-262. John H. Callomon is thanked for the identification of the ammonites. The referees, D.J. Batten and J.B. Riding, provided constructive and very helpful suggestions. 


\section{References}

Alsgaard, P.C., Felt, V.L., Vosgerau, H. \& Surlyk, F. 2003: The Jurassic of Kuhn $\varnothing$, North-East Greenland. In: Ineson, J.R. \& Surlyk, F. (eds): The Jurassic of Denmark and Greenland. Geological Survey of Denmark and Greenland Bulletin 1, $865-892$.

Århus, N. 1988: Palynostratigraphy of some Bathonian-Hauterivian sections in the Arctic, with emphasis on the Janusfjellet Formation type section, Spitsbergen. Institutt for Kontinentalsokkelundersøkelser (IKU) Report 23.1252.11/01/88, 139 pp.

Bailey, D.A. \& Hogg, N.M. 1995: Fentonia bjaerkei gen. et comb. nov.; transfer from Parvocysta Bjaerke 1980. Journal of Micropalaeontology 14, $58 \mathrm{pp}$.

Birkelund, T. \& Callomon, J.H. 1985: The Kimmeridgian ammonite faunas of Milne Land, central East Greenland. Bulletin Grønlands Geologiske Undersøgelse 153, 56 pp.

Clemmensen, L.B. \& Surlyk, F. 1976: Upper Jurassic coal-bearing shoreline deposits, Hochstetter Forland, East Greenland. Sedimentary Geology 15, 193-211.

Engkilde, M. 1994: The Middle Jurassic Vardekløft Formation, East Greenland: depositional environments and sequence stratigraphy of shallow marine sandstones deposited in a low-gradient epeiric seaway, 1-207. Unpublished Ph.D. thesis, University of Copenhagen, Denmark.

Frebold, H. 1932: Geologie der Jurakohlen des nördlichen Ostgrönland. Meddelelser om Grønland 84(5), 62 pp.

Håkansson, E., Birkelund, T., Piasecki, S. \& Zakharov, V. 1981: Jurassic-Cretaceous of the extreme Arctic (Peary Land, North Greenland). Bulletin of the Geological Society of Denmark 30, 11-42.

Milner, P.S. \& Piasecki, S. 1996: Boreal Middle Jurassic dinoflagellate cyst stratigraphy of Jameson Land, East Greenland. In: Piasecki, S. et al. (eds): Formation of source and reservoir rocks in a sequence stratigraphic framework, Jameson Land, East Greenland. Energy research programme EFP-93, projects 1313/93-0010 and 0017. Danmarks og Grønlands Geologiske Undersøgelse Rapport 1996/30, Vol. I and II, 46 pp.

Petersen, H.I., Bojesen-Koefoed, J., Nytoft, H.P., Surlyk, F., Therkelsen, J. \& Vosgerau, H. 1998: Relative sea-level changes recorded by paralic liptinite-enriched coal facies cycles, Middle Jurassic Muslingebjerg Formation, Hochstetter Forland, Northeast Greenland. International Journal of Coal Geology 36, 1-30.
Piasecki, S. 1996: Boreal dinoflagellate cyst stratigraphy of Middle to Upper Jurassic sediments of Milne Land, East Greenland. In: Piasecki, S. et al. (eds): Formation of source and reservoir rocks in a sequence stratigraphic framework, Jameson Land, East Greenland. Energy research programme EFP-93, projects 1313/93-0010 and 0017. Danmarks og Grønlands Geologiske Undersøgelse Rapport 1996/30, Vol. I and II, 100 pp.

Piasecki, S., Callomon, J.H. \& Stemmerik, L. 2004a: Jurassic dinoflagellate cysts from Store Koldewey, North-East Greenland. In: Stemmerik, L. \& Stouge, S. (eds): The Jurassic of NorthEast Greenland. Geological Survey of Denmark and Greenland Bulletin 5, 99-112 (this volume).

Piasecki, S., Larsen, M., Therkelsen, J. \& Vosgerau, H. 2004b: Jurassic dinoflagellate cyst stratigraphy of Hold with Hope, North-East Greenland. In: Stemmerik, L. \& Stouge, S. (eds): The Jurassic of North-East Greenland. Geological Survey of Denmark and Greenland Bulletin 5, 73-88 (this volume).

Ravn, J.P.J. 1911: On Jurassic and Cretaceous fossils from NorthEast Greenland. Meddelelser om Grønland 45(10), 437-500.

Smelror, M. 1987: Bathonian and Callovian (Middle Jurassic) dinoflagellate cysts and acritarchs from Franz Josef Land, Arctic Soviet. Polar Research 5, 221-238.

Smelror, M. 1993: Biogeography of Bathonian to Oxfordian (Jurassic) dinoflagellates: Arctic, NW Europe and circum-Mediterranean regions. Palaeogeography, Palaeoclimatology, Palaeoecology 102, 121-160.

Surlyk, F. 1978: Mesozoic geology and palaeogeography of Hochstetter Forland, East Greenland. Bulletin of the Geological Society of Denmark 27, 73-87.

Surlyk, F. 2003: The Jurassic of East Greenland: a sedimentary record of thermal subsidence, onset and culmination of rifting. In: Ineson, J.R. \& Surlyk, F. (eds): The Jurassic of Denmark and Greenland. Geological Survey of Denmark and Greenland Bulletin 1, 659-722.

Sykes, R.M. \& Surlyk, F. 1976: A revised ammonite zonation of the Boreal Oxfordian and its application in North-East Greenland. Lethaia 9, 421-436.

Vosgerau, H., Larsen, M., Piasecki, S. \& Therkelsen, J. 2004: A new Middle-Upper Jurassic succession on Hold with Hope, North-East Greenland. In: Stemmerik, L. \& Stouge, S. (eds): The Jurassic of North-East Greenland. Geological Survey of Denmark and Greenland Bulletin 5, 51-71 (this volume). 